\title{
Hubungan Status Gizi Terhadap Tingkat Aktivitas Fisik PMI Selama Masa Karantina COVID-19
}

\author{
I Putu Agus Dharma Hita ${ }^{1}$, Elsa Ariestika ${ }^{2}$, Betrix Teofa Perkasa Wibafiet Billy Yacshie $^{3}$, \\ Doni Pranata $^{4}$ \\ ${ }^{1}$ Program Studi Ilmu Keolahragaan, Program Pascasarjana, Universitas Negeri Yogyakarta \\ Korespondensi Penulis. E-mail: iputu.2019@student.uny.ac.id, \\ ariestikaelsa@gmail.com, betrixbilly12@gmail.com, donipranata.2019@student.uny.ac.id
}

Menerima: 02 Oktober 2020; Revisi: 28 Oktober 2020; Diterima: 30 Oktober 2020

https://doi.org/10.24036/MensSana.050220.07

\begin{abstract}
All aspects of life have adjusted during the COVID-19 outbreak. Following current conditions, it is very important to maintain body fitness by diligently carrying out sports activities, so that the body's immunity is maintained and protected from viruses and other diseases. The purpose of this study was to determine the relationship between nutritional status and level of physical activity. The sample in this study is Indonesian Migrant Workers (PMI) who carry out COVID-19 quarantine for 14 days in Jembrana Regency, Bali Province. Indonesian Migrant Workers (PMI) are sent home to Indonesia Due to the pandemic outbreak that has hit various countries where they work. This research is a type of correlational research. The instrument used was a 24-hour physical activity recall sheet for 14 days by collecting data on nutritional status and level of physical activity. After the data is collected, the normality test will be carried out using the Kolmogorov Smirnov method and the homogeneity test using the Levene statistical method, and hypothesis testing using the correlation technique. The data in this study were normally distributed and homogeneous. The results in this study indicate a significant relationship between nutritional status and PMI's level of physical activity during the COVID-19 quarantine period in Jembrana Regency. It is hoped that this research can motivate other researchers to carry out broader research related to nutritional status and levels of physical activity.
\end{abstract}

Keywords: Nutritional Status, Level of Physical Activity, COVID-19

Seluruh aspek kehidupan mengalami penyesuaian ketika terjadi wabah COVID-19. Sesuai dengan kondisi saat ini, sangat penting untuk menjaga kebugaran tubuh dengan rajin melakukan aktivitas olahraga, agar imunitas tubuh terjaga serta terhindar dari virus dan penyakit lainnya. Tujuan dalam penelitian ini yaitu untuk mengetahui hubungan status gizi terhadap tingkat aktivitas fisik. Sampel dalam penelitian ini merupakan Pekerja Migran Indonesia (PMI) yang melaksanakan karantina COVID-19 selama 14 hari di Kabupaten Jembrana, Provinsi Bali. Para Pekerja Migran Indonesia (PMI) dipulangkan ke Negara Asal Indonesia Dikarenakan wabah pandemi yang melanda di berbagai negara tempat mereka bekerja. Penelitian ini merupakan jenis penelitian korelasional. Instrumen yang digunakan yaitu lembar recall physical activity 24 jam selama 14 hari dengan mengumpukan data status gizi dan tingkat aktivitas fisik. Setelah data terkumpul akan dilakukan uji normalitas menggunakan metode kolmogorov smirnov serta uji homogenitas menggunakan metode levene statistic dan uji hipotesis menggunakan teknik korelasi. Data dalam penelitian ini berdistribusi normal dan bersifat homogen. Hasil dalam penelitian ini menunjukkan adanya hubungan yang signifikan antara status gizi dan tingkat aktivitas fisik PMI selama masa karantina COVID-19 di Kabupaten Jembrana. Diharapkan dengan adanya penelitian ini dapat memotivasi peneliti-peneliti lainnya agar melalukan penelitian yang lebih luas berkaitan dengan status gizi dan tingkat aktivitas fisik.

Kata Kunci: Status Gizi, Tingkat Aktivitas Fisik, COVID-19 


\section{PENDAHULUAN}

Pada akhir tahun 2019 munculnya infeksi virus yang menyebar secara cepat, virus tersebut dinamakan COVID-19. Virus ini pertama kali ditemukan di Wuhan, China. COVID-19 menyebar secara massif di negara-negara lainnya. World Health Organization (WHO) mengumumkan pada tanggal 11 Maret 2020 bahwa COVID-19 dinyatakan sebagai pandemi (Satrianingrum \& Prasetyo, 2020). Virus ini merupakan keluarga besar corona virus yang dapat menyerang hewan. Ketika menyerang manusia, corona virus biasanya menyebabkan penyakit infeksi saluran pernafasan, seperti flu, MERS (Middle East Respiratory Syndrome), dan SARS (Severe Acute Respiratory Syndrome) (Amri, 2020).

Dengan adanya virus COVID-19 di Indonesia saat ini berdampak bagi seluruh masyarakat. Menurut kompas, 28/03/2020 dampak virus COVID-19 terjadi diberbagai bidang seperti sosial, ekonomi, pariwisata dan pendidikan. Surat Edaran (SE) yang dikeluarkan pemerintah pada 18 Maret 2020 segala kegiatan didalam dan diluar ruangan di semua sektor sementara waktu ditunda demi mengurangi penyebaran corona terutama pada bidang pendidikan (Dewi, 2020)

Penyebaran dari virus COVID-19 sampai saat ini masih terus meluas dan mengalami peningkatan yang sangat besar. Menurut web resmi pemerintah Indonesia pada covid19.go.id pertanggal 30 Oktober 2020, jumlah individu diseluruh dunia yang terkonfirmasi positif COVID-19 yaitu sebanyak 44.592.789 orang dan meninggal sebanyak 1.175.553 orang. Sedangkan di Indonesia, jumlah individu yang terkonfirmasi positif sebanyak 406.945 orang, sembuh sebanyak 334.295 orang, dan meninggal sebanyak 13.782. Hal ini terjadi akibat belum terdapat vaksin yang mumpuni untuk mengobati pasien yang positif menderita COVID-19. Karena proses tertular COVID-19 yang sangat relatif cepat maka, organisasi kesehatan dunia (WHO) menyatakan virus ini sebagai pandemi. Wabah ini di tandai dari tingginya penyebaran COVID-19 di dunia (WHO, 2020).

Efek dalam proses tertularnya wabah COVID-19 ini hampir semua penduduk di Dunia mengambil langkah antisipasi dengan pembatasan kegiatan yang ada di negaranya, bahkan ada beberapa negara yang melakukan lockdown (Susanto, 2020). Maksud dalam lockdown ini adalah seperti menutup swalayan, wisata, bahkan tempat beribadah, tujuannya agar mengurangi dampak penyebaran virus COVID-19.

Locdown dipilih oleh berbagai negara di dunia, hal ini dikarenakan melalui Lockdwon virus yang tersebar dapat ditekan supaya tidak menyebarkan ke orang lain. Dikerumunan tersebut virus mudah tertular dan mudah di tularkan karena gejala COVID-19 ini seperti gejala flu pada umumnya yang menyebabkan seseorang yang terkontaminasi COVID-19 tidak merasa bahwa dirinya positf corona melainkan dia merasa bahwa dirinya hanya flu biasa. Adapun gejala-gejala COVID-19 yaitu demam, batuk, dan sesak napas. Sedangkan terdapat kondisi yang berat menyebabkan pneumonia, pernapasan akut, gagal ginjal, dan kematian (Syahruddin, 2020).

Namun efek samping dari di berlakunya lockdown ini adalah pemberhentian pekerja yang berasal dari daerah maupun negara-negara lain dan pekerja yang berasal dari Indonesia, disebut Pekerja Migran Indonesia (PMI). Pemberhentian pekerja tersebut akibat COVID-19 ini menyebabkan di pulangkannya kembali ke Indonesian dan di pulangkan ke daerah masingmasing.

Untuk mengatasi pandemi sebaran virus ini, masyarakat di himbau agar melakukan social distance (Kemenkes, 2020). Bagi para pekerja kantoran pekerjaan dilakukan dirumah atau work from home (WFH) termasuk pekerja yang berada di luar negeri yang dipulangkan ke negaranya masing- masing. Termasuk PMI yang berasal dari Kabupaten Jembrana, Provinsi Bali yang berjumlah 343 PMI terdiri dari 265 pria dan 75 wanita dari tanggal 21 Mei 2020 (BPBD, 2020). Mengacu dari kebijakan Kabupaten Jembrana, bahwa setiap PMI yang hadir dari luar daerah ataupun dari negara lain di wajibkan melakukan karantina mandiri 14 hari di penginapan yang sudah disediakan Pemerintah Daerah Jembrana, Bali.

Karantina mandiri selama 14 hari yang dilakukan dan dihimbau para PMI harus berolahraga karena saat melakukan aktifitas fisik tubuh akan menjadi berkeringat yang membuat tubuh semakin bugar dan dapat mengontrol hormon kortisol (Yuliana, 2020). Kurangnya melakukan aktivitas fisik dapat berpengaruh pada kekebalan tubuh karena pada dasarnya saat tubuh tidak di paksa melakukan aktifitas fisik maka imunitas tubuh juga bisa menurun dan mudah 
terserang penyakit/virus namun dengan memperhatikan intensitas dari latihan fisik yang akan di lakukan (Abdulloh, 2020).

Selain aktifitas fisik, asupan makanan yang masuk kedalam tubuh harus di kontrol juga karena penting sebagai anti body dari berbagai virus (Ayseli et al., 2020). Asupan makanan merupakan segala sesuatu bentuk makanan yang dicerna oleh sistem pencernaan. Dengan asupan makanan yang tepat yaitu tidak mengkonsumsi makan yang salah seperti mengkonsumsi makanan dalam jumlah yang sangat banyak, tinggi lemak, karbohidrat berlebihan, dan rendah serat namun tidak di imbangi dengan pengeluaran energi yang seimbang ini merupakan salah satu penyebab dari terjadinya kasus overweight atau kelebihan berat badan.

Asupan makanan tinggi lemak dan kalori dapat menyebabkan obesitas. Faktor yang menyebabkan obesitas yaitu: riwayat obesitas orang tua, kurang sayur, buah dan terbiasa merokok (Dewi, 2015). Seorang individu masuk dalam kategori overweight apabila nilai dari IMT (Indeks Massa Tubuh) lebih dari 23 (23 s.d. 24,9). Sedangkan dapat dinyatakan sebagai obesitas apabila memiliki nilai IMT lebih dari 25 (>25) menurut kriteria Asia Pasifik (P2PTM Kemenkes RI, 2020).

Sebagian besar populasi di seluruh dunia yang tinggal di negara besar dimana overweight dan obesitas ini dapat membunuh lebih banyak karena dari asupan makanan dan aktifitas fisik yang kurang seimbang, sedangkan untuk kasus kekurangan berat badan atau kasus kurang gizi lebih sedikit di bandingkan dengan kasus overweight dan obesitas (Frayon et al., 2020). Karena pengobatan yang efektif untuk COVID19 belum ditemukan yang memiliki resiko sangat tinggi, dengan memperhatikan status gizi ini sebagai langkah awal, dalam perawatan dan manajement pasien COVID-19 dengan memperhatikan nutrisi dan gizi seimbang (Fedele et al., 2020).

Menurut peraturan pemerintah diperlukanya karantina terbelih dahulu sebelum mereka dapat kembali dapat beraktivitas normal. Berkaitan mengenai program tentang karantina, Pemerintah Kabupaten Jembrana juga melakukan program karantina yang bertujuan untuk mencegah penyebaran dari COVID-19, yang dimana angka kejadian penyebaran virus ini di Kabupaten Jembrana per tanggal 1 Oktober 2020 berdasarkan data dari Web Resmi Pemerintah Kabupaten Jembrana sudah mencapai 302 orang positif, 232 orang sembuh, dan 6 orang meninggal. Berdasarkan pemaparan tersebut, penelitian ini akan mengungkapkan mengenai hubungan aktivitas fisik dan status gizi PMI pada saat melakukan karantina COVID-19 selama 14 hari. Penelitian ini sangat perlu dilakukan dikarenakan kedepannya dapat menjadi suatu rujukan untuk daerah bahkan negara lain dalam melakukan karantina COVID-19, selain itu sangat penting dalam memperhatikan asupan nutrisi/makanan serta aktivitas fisik. Dengan melakukan hal tersebut dapat meningkatkan imunutas tubuh dan melawan virus yang menyerang kekebalan ataupun imuntas tubuh. Hasil penelitian juga diharapkan mampu menjadi rujukan penelitian selanjutnya.

\section{METODE}

Jenis penelitian ini yaitu korelasional yang dilakukan untuk mencari apakah terdapat hubungan antara variabel satu dengan variabel lainnya. Untuk melakukan penelitian ini diperlukan waktu selama 3 bulan yang dilaksanakan dari bulan April hingga bulan Juni tahun 2020. Penelitian ini dilakukan di Kabupaten Jembrana, Provinsi Bali.

Sampel dikategorikan menggunakan metode purposive samping, yaitu penentuan sampel didasarkan dari kriteria-kriteria yang ditentukan. Maka dari itu, sampel yang terkumpul sebanyak 86 PMI, yang terdiri dari 67 pria dan 19 wanita. Kriteria karakteristik sampel dalam penelitian ini yaitu merupakan Pekerja Migran Indonesia (PMI) yang dipulangkan ke Indonesia dikarenakan pandemi COVID-19, mengikuti program pemerintah daerah yaitu melakukan karantika 14 hari di hotel-hotel yang sudah disediakan, dan bersedia menjadi sampel penelitian dari awal sampai akhir.

Instrumen pada penelitian ini menggunakan lembar recall physical activity 24 jam selama 14 hari dengan mengumpukan data status gizi dan tingkat aktivitas fisik. Untuk mengukur status gizi dilakukan dengan cara mengetahui tinggi badan dan berat badan, setelah itu memakai rumus indeks massa tubuh (IMT) yaitu:

Berat Badan (kg) Tinggi Badan $\left(\mathrm{m}^{2}\right)$

Tabel 1. Kategori IMT Berdasarkan Kriteria Asia Pasifik WHO Tahun 2000 
(P2PTM Kemenkes RI, 2020)

\begin{tabular}{llrrrr}
\hline & & \multicolumn{3}{c}{ Tingkat Aktivitas Fisik } & N \\
\cline { 3 - 6 } & & $\begin{array}{c}\text { Sangat } \\
\text { Rendah }\end{array}$ & Rendah & Sedang \\
\hline Status & Normal & 0 & 37 & 7 & 44 \\
Gizi & Overweight & 0 & 22 & 1 & 23 \\
& Obesitas I & 0 & 15 & 0 & 15 \\
& Obesitas II & 1 & 3 & 0 & 4 \\
\hline Total & & 1 & 77 & 8 & 86 \\
\hline
\end{tabular}

Tingkat aktivitas fisik dinyatakan dalam Physiscal Activity Level (PAL). PAL adalah besarnya nilai dari Physical Activity Ratio (PAR) yang dikeluarkan dalam 24 jam (FAO, 2001). PAL ditetapkan menggunakan rumus:

$$
\text { PAL }=\frac{\sum(P A R)}{24}
$$

Keterangan:

PAL : Physical Activity Level

PAR : Physical Activity Ratio

W : Alokasi Waktu 24 Jam

Hasil perhitungan aktivitas fisik dapat diklasifikasikan yaitu di bawah ini :
1. Sangat Ringan $=<1,40 \mathrm{PAL}$
2. Ringan $=1,40-1,69 \mathrm{PAL}$
3. Sedang $=1,70-1,99 \mathrm{PAL}$
4. Berat $=2,00-2,40$ PAL
5. Sangat Berat $=>2,40 \mathrm{PAL}$

Data yang telah terkumpul hendak dicoba uji normalitas dengan teknik kolmogorov smirnov serta uji homogenitas memakai teknik levene statistic dengan taraf signifikan 5\% ( $>00.05)$. Kemudian akan dilanjutkan dengan uji hipotesis menggunakan teknik korelasi dengan taraf signifikan 5\% $(\mathrm{p}<0.05)$.

\section{HASIL DAN PEMBAHASAN Hasil}

Berdasarkan tabel diatas dapat dilihat bahwa pada status gizi kategori normal terdapat 37 PMI dengan tingkat aktivitas fisiknya rendah, dan 7 PMI dengan tingkat aktivitas fisiknya sedang. Untuk status gizi kategori overweight terdapat 22 PMI dengan tingkat aktivitas fisiknya rendah, dan 1 PMI dengan tingkat aktivitas fisiknya sedang.

Tabel 2. Distribusi Frekuensi Status Gizi Tabel 2. Distribusi Frekuensi Status Gizi

\begin{tabular}{llrrrr}
\hline & & \multicolumn{3}{c}{ Tingkat Aktivitas Fisik } & N \\
\cline { 3 - 6 } & & $\begin{array}{c}\text { Sangat } \\
\text { Rendah }\end{array}$ & Rendah & Sedang & \\
\hline Status & Normal & 0 & 37 & 7 & 44 \\
& Overweight & 0 & 22 & 1 & 23 \\
& Obesitas I & 0 & 15 & 0 & 15 \\
& Obesitas II & 1 & 3 & 0 & 4 \\
\hline Total & & 1 & 77 & 8 & 86 \\
& & &
\end{tabular}

Berdasarkan Tingkat Aktivitas Fisik Untuk status gizi kategori obesitas I hanya terdapat 15 PMI dengan tingkat aktivitas fisiknya rendah, sedangkan untuk status gizi kategori obesitas II terdapat 1 PMI dengan tingkat aktivitas fisiknya sangat rendah, serta 3 PMI dengan tingkat aktivitas fisiknya rendah. Di bawah ini terdapat tabel 3 yang memaparkan hasil uji normalitas dari data status gizi dan tingkat aktivitas fisik yaitu sebagai berikut:

Tabel 3. Uji Normalitas

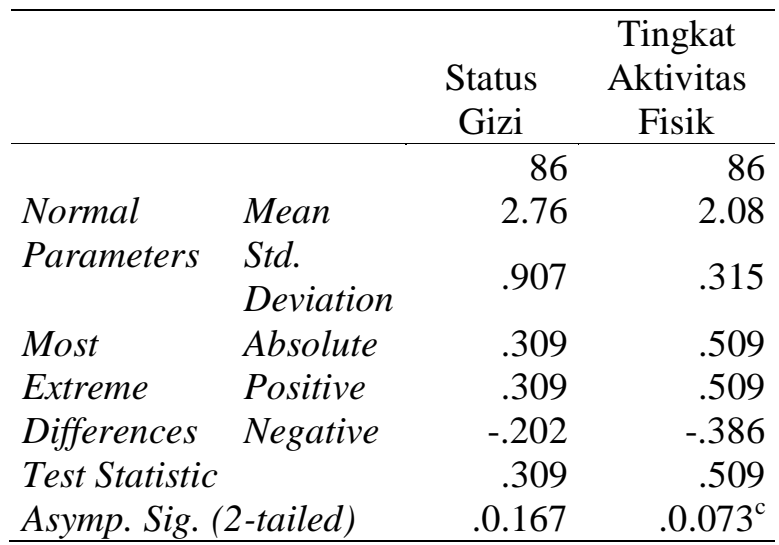

Berdasarkan hasil uji normalitas pada tabel 3 di atas dengan menggunakan teknik kolmogorov smirnov, hasil yang diperoleh yaitu nilai sig 0.167 (status gizi), dan nilai sig 0.073 (tingkat aktivitas fisik) $\mathrm{p}>0.05$. Kesimpulan dari hasil tersebut menunjukkan bahwa untuk data status gizi dan tingkat aktivitas fisik pada penelitian ini berdistribusi normal.

Tabel 4. Uji Homogenitas

Test of Homogeneity of Variances

Levene Statistic df1 df2 Sig.

$\begin{array}{llll}8.741 & 3 & 82 & .133\end{array}$

Berdasarkan tabel uji homogenitas di atas menggunakan teknik levene statistic, memiliki hasil yang diperoleh yaitu nilai sig 0.133 ( $>0.05)$. Kesimpulan hasil uji di atas adalah data pada penelitian ini bersifat homogen. Di bawah ini merupakan tabel 5 untuk uji korelasi variabel status gizi terhadap tingkat aktivitas 
Jurnal ilmiah Bidang Pendidikan Olahraga

Edisi November

Volume 5, Nomor 2, Tahun 2020: 146-156

fisik, hasil tersebut dapat dipaparkan sebagai berikut:

\begin{tabular}{ccccc}
\multicolumn{5}{c}{ Tabel 5. Uji Korelasi } \\
\hline Model & $\begin{array}{c}\text { Sum of } \\
\text { Squares }\end{array}$ & df & F & Sig. \\
\hline Regression & .761 & 1 & 8.332 & $.005^{\mathrm{b}}$ \\
Residual & 7.669 & 84 & & \\
Total & 8.430 & 85 & & \\
\hline
\end{tabular}

Berdasarkan hasil tabel uji korelasi yang telah dipaparkan diatas, terdapat hasil yang diperoleh yaitu nilai sig. $0.005(\mathrm{p}<0.05)$, maka kesimpulannya adalah terdapat hubungan secara signifikan antara status gizi terhadap tingkat aktivitas fisik.

\section{Pembahasan}

Tujuan dari penelitian ini adalah untuk mengetahui hubungan status gizi terhadap tingkat aktivitas fisik PMI yang melaksanakan karantina COVID-19 di Kabupaten Jembrana, Provinsi Bali selama 14 hari. Pada temuan ini menunjukkan hasil pengukuran status gizi terhadap aktifitas fisik memiliki hubungan yang signifikan. Hasil penelitian ini sejalan dengan penelitian (Anggraini \& Mexitalia, 2014) yang menunjukan hasil bahwa terdapat hubungan yang bermakna antara aktivitas fisik dengan status gizi pada anak usia prasekolah dengan gizi normal dan gizi lebih dari normal. Oleh karena itu Aktivitas fisik sangat penting dilakukan karena berkaitan dengan daya tahan tubuh sesorang.

Dengan menjaga kebugaran tubuh melalui aktivitas berolahraga disertai dengan meningkatknya imunitas tubuh yang optimal. Sehingga, terhindar dari berbagai macam serangan virus yang merugikan kondisi tubuh. Pernyataan dari (WHO, 2010) dengan kurangnya melakukan aktivitas fisik merupakan aspek pemicu kematian di seluruh dunia yang disebabkan oleh obesitas serta kegemukan. Bersumber pada uraian ini dapat menunjukkan aktivitas fisik ialah hal berarti dalam memperoleh suatu kesehatan yang besar.

Berdasarkan penjelasan di atas terdapat hasil penelitian yang sesuai analisis data dalam penelitian ini yaitu status gizi yang tinggi menghasilkan rendahnya tingkat aktivitas fisik yang dilakukan. Dari hasil analisis data diperoleh jumlah PMI yang memiliki status gizi normal terdapat 37 PMI dalam kategori ringan dan 7 PMI dalam kategori sedang, sedangkan PMI yang memiliki status gizi overweight terdapat 22 PMI dalam kategori ringan dan 1 PMI termasuk dalam

status gizi obesitas 1 dapat diperoleh 15 PMI dalam kategori ringan, sedangkan untuk PMI yang memiliki status gizi obesitas II terdapat 1 PMI dalam kategori sangat ringan dan terdapat 3 PMI dalam kategori ringan.

Dari data penelitian tersebut, menunjukkan bahwa dengan tingginya status gizi seseorang maka berpengaruh terhadap rendahnya tingkat aktivitas fisik yang dilakukan. Hal tersebut sesuai dengan hasil riset yang menunjukkan tingkat status gizi dan aktivitas fisik dengan rata-rata yang cukup untuk memenuhi kebutuhan energi dan protein pada status gizi dan aktifivitas fisik menurun (Bénéfice et al., 2001). Menjaga tingkat aktivitas fisik agar selalu baik sangat besar pengaruhnya terhadap berat badan. Semakin rendah tingkat aktivitas fisik yang dilakukan maka semakin besar kemungkinan terjadi berat badan berlebih. Hal ini didukung dengan penelitian sebelumnya yang menunjukkan terdapat kontribusi pada aktivitas fisik dengan pembinaan gaya hidup sehat membutuhkan pengetahuan agar tidak terjadi peningkatan berat badan yang berlebih (Rutten et al., 2014).

Dimasa pandemi COVID-19 sangat penting untuk menjaga pola aktivitas fisik yang baik serta asupan makanan yang dikonsumsi dikarenakan kedua hal tersebut sangat berpengaruh terhadap imunitas seseorang sehingga mampu terhindar dari berbagai serangan penyakit ataupun virus lainnya. Faktor olahraga sangat besar pengaruhnya agar imunitas tubuh selalu terjaga.

Olahraga yang baik dilakukan untuk menjaga imunitas tubuh adalah melakukan olahraga dengan intensitas sedang namun durasi yang lebih lama. Pernyataan tersebut sejalan dengan penelitian yang menunjukakan bahwa melakukan olahraga sesi menghasilkan tingkat kortisol yang ditekan di malam hari, dan besarnya efek ini bergantung pada intensitas di mana olahraga di malam hari, dan efeknya bergantung pada intensitas yang sudah terbentuk dari intensitas rendah menuju sedang dengan durasi yang lebih lama pada aktivitas olahraga (Hackney \& Viru, 2015).

Dengan keterbatasan jarak sesuai aturan pemerintah dimana setiap individu wajib jaga jarak dan melakukan pola hidup sehat dengan memakai masker, mencuci tangan, serta beberapa aturan lainnya, sangat tidak mungkin akan berpengaruh terhadap ruang gerak kita dalam melakukan aktivitas olahraga. Maka dari itu, 
sangat penting bagi kita untuk dapat melakukan aktivitas olahraga dengan menerapkan protokol kesehatan. Daya tahan tubuh atau sistem imunitas yang baik dapat melindungi kita sejak pertama kali virus penyebab penyakit masuk ke dalam tubuh. Oleh karena itu, memiliki daya tahan tubuh atau imun yang kuat sangat penting untuk mencegah seseorang tertular penyakit, terutama di masa mewabahnya virus COVID-19.

Berdasarkan temuan hasil penelitian Blair (2012) yang mengatakan hubungan status gizi serta aktivitas fisik sangat erat kaitannya. Hal ini sesuai penelitian yang mengungkapkan bahwa seseorang yang mempunyai berat badan berlebihan tetapi memiliki aktivitas yang baik sangat memungkinkan untuk mempunyai status gizi normal dari pada seseorang yang mempunyai status gizi normal tetapi tidak sehat dikarenakan rendahnya aktivitas fisik yang dilakukan (Nhantumbo et al., 2013).

Imunitas tubuh dapat bekerja dengan optimal dan sempurna dikarenakan pola hidup sehat dapat berpengaruh pada kesehatan tubuh sehingga tubuh tidak mudah terserang penyakit. Pentingnya untuk menerapkan pola hidup sehat ini di dukung dengan penelitian (Kang et al., 2020) yang menyatakan hidup sehat adalah segala aspek untuk menambah usia seseorang karena jika gaya hidup tidak sehat seperti mengkonsumsi junk food, kurang sayur, merokok, dan mengkonsumsi alkohol ini menyebabkan kerusakan di jaringan sel sel tubuh. Sementara itu Menurut (Adliyani, 2015) Sehat dapat di pengaruhi oleh perilaku seseorang, perilaku yang dimiliki oleh manusia dan dipengaruhi oleh adat, sikap, emosi, nilai, etika, kekuasaan, persuasi, dan atau genetika.

Selaras dengan (Ferreira et al., 2020) langkah yang bisa ditempuh untuk menjaga dan meningkatkan imunitas tubuh yaitu seperti perbanyak makan sayur dan buah. Untuk menjaga dan meningkatkan imunitas tubuh, sangat disarankan untuk memperbanyak konsumsi sayur dan buah.

Orang yang banyak mengonsumsi kedua jenis makanan tersebut, cenderung tidak mudah sakit. Hal ini karena vitamin dan mineral yang terkandung dalam sayur dan buah mampu memperkuat sistem kekebalan tubuh dalam melawan virus dan bakteri penyebab penyakit. Vitamin dan mineral memainkan peranan penting dalam mengatur dan membantu reaksi kimia zat gizi penghasil energi, sebagai koenzim dan $\mathrm{k} \mathrm{o}$ faktor (Nugroho, 2015)

Sangat disarankan untuk rutin melakukan aktivitas fisik selama 30 menit setiap hari, untuk meningkatkan sistem kekebalan tubuh dalam melawan infeksi. Salah satu olahraga yang murah dan mudah untuk dilakukan adalah berjalan kaki. Tak hanya di luar rumah, olahraga atau aktivitas fisik juga bisa dilakukan di dalam rumah. Selain hal tersebut, cara selanjutnya adalah hindari rokok dan alcohol, karena rokok dan alkohol secara berlebih dapat merusak sistem kekebalan tubuh.

Perokok memiliki risiko tinggi untuk mengalami infeksi paru, seperti bronkitis dan pneumonia. Sementara untuk perokok yang juga pecandu alkohol, risiko untuk terkena infeksi paru akan semakin besar. Selain menerapkan pola hidup sehat, sebagian orang memilih untuk mengonsumsi suplemen/vitamin untuk meningkatkan imunitas tubuh bisa di lakukan. Konsumsi suplemen ini mungkin dapat menjadi pilihan untuk melengkapi pola makan yang kurang bernutrisi. Jika kita mempertimbangkan untuk mengonsumsi suplemen peningkat imunitas tubuh, perhatikan kandungan yang terdapat pada suplemen tersebut.

Berdasarkan penelitian (Corrado et al., 2020) beberapa kandungan berikut ini dapat bermanfaat meningkatkan imunitas atau daya tahan tubuh seperti echinacea, morinda citrifolia, phylantus, vitamin B6, C, dan vitamin E. Suplemen yang mengandung echinacea cukup direkomendasikan. Selain mampu meningkatkan sistem kekebalan tubuh, echinacea dipercaya bermanfaat sebagai antivirus, antiradang, dan antioksidan.

Oleh karena itu, bahan ini diyakini dapat membantu tubuh melawan virus penyebab flu, membantu pertumbuhan sel, serta mengontrol gula darah dan tekanan darah. Morinda atau buah mengkudu ini mengandung berbagai macam zat yang dibutuhkan tubuh. Misalnya kalium yang terkandung pada mengkudu, mampu meningkatkan stamina dan kekebalan tubuh, serta memperbaiki kerusakan sel.

Namun, individu yang memiliki riwayat penyakit ginjal, jantung, atau penyakit liver, disarankan untuk menghindari konsumsi suplemen yang mengandung mengkudu. Sebaiknya konsultasi ke dokter sebelum mengonsumsi suplemen ini. Phylantus atau daun meniran meski memerlukan penelitian lebih 
lanjut, daun meniran dianggap mengandung berbagai macam senyawa yang bermanfaat untuk kesehatan. Misalnya kandungan antioksidan yang terdapat dalam daun meniran, berfungsi melawan radikal bebas dan memperkuat sistem imun tubuh.

Suplemen yang mengandung vitamin B6, vitamin $\mathrm{C}$ dan vitamin $\mathrm{E}$ cukup direkomendasikan. Ketiga vitamin ini dapat memberi manfaat bagi tubuh untuk meningkatkan sistem kekebalan tubuh lebih optimal. Menerapkan pola hidup sehat merupakan langkah terbaik dalam menjaga dan meningkatkan imunitas tubuh. Hasil riset dengan statment (Blair, 2012) yang mengatakan hubungan status gizi serta aktivitas fisik sangat erat kaitannya.

Aktivitas fisik ialah satu dari bagian aspek yang mempengaruhi terhadap status gizi. Hal ini juga didukung oleh penelitian yang sejalan yang menunjukkan bahwa tingginya tingkat aktivitas fisik, kelebihan berat badan mempengaruhi status gizi yang tinggi (Melo et al., 2016). Status gizi individu bergantung pada zat gizi yang dikonsumsi melalui aktivitas. Nutrisi berperan penting dalam penyembuhan penyakit. Kesalahan pengaturan diet dapat memperlambat penyembuhan penyakit.

Dengan nutrisi akan memberikan makananmakanan tinggi kalori, protein dan cukup vitamin-mineral untuk mencapai status gizi optimal. Nutrisi gizi buruk diawali dengan pemberian makanan secara teratur, bertahap, porsi kecil, sering dan mudah diserap (Krisnansari, 2010).

$$
\text { Menurut penelitian (Dewi \& }
$$
Wuryaningsih, 2019) orang yang berusia lanjut memiliki kecenderungan yang kurang untuk melakukan aktivitas fisik dan rentan dengan penyakit, sesungguhnya aktivitas fisik seperti berolahraga merupakan langkah pencegahan primer untuk menurunkan kejadian suatu penyakit karena kurangnya aktifitas fisik merupakan salah satu faktor risiko yang dapat menyebabkan kematian.

Berbagai aktivitas dapat dilakukan. Aktifitas fisik dapat di lakukan dalam mengisi waktu luang. Contohnya adalah dengan melakukan kegiatan perorangan maupun berkelompok, baik kegiatan yang ringan, sedang atau berat di sini setiap kegiatan tersebut melibatkan kegiatan fisik, maka kegiatan ini dilakukan dalam mengisi waktu luang secara
Menurut (Darus, 2016) aktivitas fisik ialah gerakan tubuh oleh otot tubuh dan sistem penunjangnya yang memerlukan pengeluaran energi yang bisa di lakukan kapan saja di mana saja. Menurut (Kosasi et al., 2014) Manfaat aktivitas fisik yang dilakukan secara teratur adalah membantu meningkatkan dan menjaga kesehatan otot dan tulang, membantu mengurangi risiko terjadinya obesitas dan penyakit kronik seperti diabetes dan penyakit jantung, serta mengurangi perasaan depresi. Pengukuran aktifitas fisik biasanya digambarkan dengan istilah pengeluaran energi dan dapat ditunjukkan antara lain oleh jumlah kerja, lamanya waktu melakukan aktifitas fisik, sebagai unit gerakan (Hillbruner \& Egan, 2008).

Ada penyebab terjadinya kekurangan gizi yaitu ketidak seimbangan gizi dalam makanan yang dikonsumsi dan terjangkitnya penyakit infeksi secara tidak langsung menyebabkan ketahanan pangan di keluarga, pola pengasuhan anak dan pelayanan kesehatan kurang maksimal (Pahlevi A.E, 2012). Menurut (Hanum et al., 2014) dampak yang diakibatkan kekurangan gizi adalah meningkatnya kejadian kesakitan bahkan kematian ada pun beberapa dari mereka yang masih dapat bertahan hidup akibat kekurangan gizi yang membuat kualitas badan mempunyai asupan yang sangat rendah dan tidak seimbang.

Selama masa karantina COVID-19 Pekerja Migran Indonesia (PMI) tidak merasa kesulitan untuk konsumsi makanan yang sehat. Sebab, dengan harapan yang besar tidak bertambah status yang terkena positif COVID-19 maka, status gizi sangat diperhatikan. Salah satu faktor yang paling penting untuk dikonsumsi yaitu karbohidrat, sebab, jika karbohidrat lebih akan disimpan dalam bentuk glikogen yang menghasilkan sumber energi dalam jaringan otot serta pula dalam wujud lemak yang hendak ditaruh dalam jaringan jaringan adipose, bagian bawah kulit (Dewi \& Mahmudiono, 2013). Karbohidrat sebagai zat gizi merupakan nama kelompok zat-zat organik yang mempunyai struktur molekul yang berbeda-beda, meski terdapat persamaan-persamaan dari sudut kimia dan fungsinya. Semua karbohidrat terdiri atas unsur Carbon (C), hidrogen $(\mathrm{H})$, dan oksigen $(\mathrm{O})$ (Siregar, 2014)

Dalam mencapai pertumbuhan dan perkembangan yang baik membutuhkan nutrisi yang baik. Makanan berkualitas rendah akan menyebabkan malnutrisi. Malnutrisi dapat menyebabkan masalah bagi tumbuh kembang 
(Gunawan et al., 2016) Selain status gizi, ditinjau dari aktivitas fisik, meskipun hal itu sangat penting akan tetapi, Pekerja Migran Indonesia (PMI) tidak dominan melakukan aktivitas fisik.

Hal yang lebih sering dilakukan adalah berjemur dibawah sinar matahari agar mendapat sumber vitamin D yang didapatkan secara alami mencapai $80 \%$. Sesuai dengan penelitian yang menunjukkan bahwa efek dominan dari vitamin D ialah dikeluarkan melalui endokrin dan tindakan dari autokrin dari calcitriol melalui aktivitasi reseptor vitamin $\mathrm{D}$ dalam sel dengan hambatan lebih lanjut memproduksi vitamin D mempengaruhi kesehatan (Kennel et al., 2010). Dengan mendapatkan sinar matahari dilakukan lebih pagi dengan waktu yang relatif lama dan dilakukan secara teratur (Setiati, 2008). Sehingga sesuai dengan hasil riset ini sejalan dengan teori bahwa pengeluaran energi yang lebih rendah maka menyebabkan terjadinya kondisi obesitas (Budiyanto, 2002).

Menurut penelitian Amelia \& Syauqy (2014) kelebihan lemak dalam tubuh dapat disebabkan oleh ketidakseimbangan energi dalam tubuh, yaitu asupan energi yang lebih banyak dari pada pengeluaran energi dalam jangka waktu yang lebih lama. Energi yang berlebih di dalam tubuh akan diubah menjadi trigliserida dan disimpan di jaringan adiposa berupa lemak tubuh. Perubahan gaya hidup menyebabkan pola makan PMI yaitu pola makan tinggi kalori, tinggi lemak dan tinggi kolesterol, serta ketidak seimbangan dengan olahraga yang dapat menimbulkan masalah gizi. (Hidayati, 2010) karena interaksi antara makanan, tubuh manusia, dan lingkungan manusia, status gizi adalah keadaan kesehatan.

Latihan fisik menentukan kesehatan seseorang. Energi yang berlebihan akibat aktivitas fisik yang rendah meningkatkan risiko terjadinya kondisi berat badan berlebih dan obesitas (Mahardika, A, 2008). Keseimbangan gizi adalah pengaturan makanan sehari-hari yang mengandung jenis dan jumlah zat gizi yang dibutuhkan tubuh manusia memahami prinsip diversifikasi atau diversifikasi pangan, aktivitas fisik, kebersihan, dan berat badan ideal. Visualisasi Prinsip Gizi Seimbang (PGS) sesuai dengan budaya lokal dan kebiasaan makan. Penilaian status gizi menggunakan berbagai parameter antropometri sebagai dasar. Kombinasi beberapa parameter disebut indeks antropometri. Metode antropometri dapat digunakan untuk menilai status gizi remaja menggunakan indeks massa tubuh (IMT), lingkar lengan atas, dan lingkar perut.

Pada umumnya, orang Indonesia makan tiga kali sehari, yaitu sarapan pagi, makan siang, dan makan malam. Pertumbuhan membutuhkan makanan perkembangannya, terutama pubertas. Kurangi konsumsi makanan baik kuantitas dan kualitas menyebabkan gangguan proses metabolisme dalam tubuh tentu saja akan menyebabkannya penyakit (Almatsier, 2010). Status gizi dipengaruhi secara tidak langsung oleh usia, jenis kelamin, dan latihan fisik. Ketiga faktor tersebut mempengaruhi tingkat kebutuhan gizi dan dengan demikian mempengaruhi keadaan nutrisi.

Berdasarkan komponen hasil analisis data dan pembahasan di atas yaitu terdapat hubungan antara status gizi dengan tingkat aktivitas fisik PMI selama melaksanakan karantina COVID-19 di Kabupaten Jembrana, Provinsi Bali. Keterbatasan dalam penelitian ini yaitu masih terdapat PMI yang tidak mengikuti penelitian ini dikarenakan PMI tersebut merupakan pasien positif COVID-19, selain itu variabel yang diteliti dalam penelitian ini masih sedikit.

\section{KESIMPULAN}

COVID-19 menjadi topik pemberitaan paling utama. Dengan meningkatkan daya tahan tubuh dan konsumsi makanan yang sehat menjadi satu kesatuan cara yang paling tepat untuk menghadapi situasi saat ini. Kesimpulan dari hasil penelitian ini adalah terdapat hubungan yang signifikan status gizi terhadap tingkat aktivitas fisik PMI selama masa karantina COVID-19 di Kabupaten Jembrana. Dengan adanya temuan pada penelitian ini, diharapkan pemerintah dapat menindak lanjuti penanganan orang yang sedang berada di dalam pengawasan maupun pasien yang terdampak COVID-19 untuk tetap diberi asupan gizi yang seimbang sehingga para pasien dapat tetap melakukan aktivitas fisik seperti normal.

Penelitian ini dapat berkontribusi untuk memberikan masukan kepada pihak penyelenggara kesehatan bagi korban yang terdampak COVID-19 karena Setelah para pasien mendapatkan apa yang telah menjadi hak mereka, hal ini mendukung mereka agar dapat tetap aktif melakukan aktivitas fisik selama karantina sehingga dapat mempercepat proses penyembuhan melalui meningkatkan imun tubuh dan kebal terhadap penyakit yang lainnya. 


\section{DAFTAR PUSTAKA}

Abdulloh, N. (2020). Kesalahan Olahraga saat pandemi. Airlangga University.

Adliyani, Z. O. N. (2015). Pengaruh perilaku individu terhadap hidup sehat. Jurnal Majority, 4(7), 109-114.

Almatsier. (2010). Prinsip Dasar Ilmu Gizi. Jakarta: Gramedia Pustaka Utama.

Amelia, I. N., \& Syauqy, A. (2014). Hubungan Antara Asupan Energi Dan Aktivitas Fisik Dengan Persen Lemak Tubuh Pada Wanita Peserta Senam Aerobik. Journal of Nutrition College, 3(1), 200-205. https://doi.org/10.14710/jnc.v3i1.4559

Amri, A. (2020). Dampak Covid-19 terhadap UMKM di Indonesia. Branda Jurnal Ilmiah Manajemen Pemasaran, 2(1), 123131.

Ayseli, Y. I., Aytekin, N., Buyukkayhan, D., Aslan, I., \& Ayseli, M. T. (2020). Food policy, nutrition and nutraceuticals in the prevention and management of COVID-19: Advice for healthcare professionals. Trends in Food Science and Technology, 105(March), 186-199. https://doi.org/10.1016/j.tifs.2020.09.001

BPBD, J. (2020). Data Rekapan PMI Jembrana 21 Mei 2020. Badan Penanggulangan Bencana Daerah Kabupaten Jembrana.

Budiyanto, M. . (2002). Gizi dan Kesehatan. Malang: UMM Press.

Corrado, D., Magnano, P., Muzii, B., Coco, M., Guarnera, M., Lucia, S. De, \& Mauro, N. (2020). Effects of social distancing on psychological state and physical activity routines during the COVID - 19 pandemic. Sport Sciences for Health, 0123456789, 16. https://doi.org/10.1007/s11332-02000697-5

Dewi, A., \& Mahmudiono, T. (2013). Hubungan Pola Makan, Aktivitas Fisik, Sikap, dan Pengetahuan Tentang Obesitas dengan Status Gizi Pegawai Negeri Sipil di Kantor Dinas Kesehatan Provinsi Jawa Timur. Jurnal Media Gizi Indonesia, 9(1), 42-48.
Dewi, I. G., \& Wuryaningsih, C. E. (2019). Aktivitas Fisik Masyarakat Urban di Jakarta Selatan. Hasanuddin Journal of Midwifery, $\quad 1(1), 23$. https://doi.org/10.35317/hajom.v1i1.1790

Dewi, M. C. (2015). Faktor-Faktor yang Menyebabkan Obesitas pada Anak. Majority, 4(8), 53-56.

Dewi, W. A. F. (2020). Dampak Covid-19 terhadap implementasi pembelajaran daring di Sekolah Dasar. Edukatif: Jurnal Ilmu Pendidikan, 2(1), 55-61.

FAO. (2001). Human Energy Requirements. Food and Nutrition Technical Report Series, 26(1), 166.

Fedele, D., De Francesco, A., Riso, S., \& Collo, A. (2020). Obesity, Malnutrition and Trace Elements Deficiency in the COVID-19 Pandemic: an Overview. Nutrition, 111016. Journal Nutrition, 86 (1), 1-7. https://doi.org/10.1016/j.nut.2020.111016

Ferreira, L., Vinícius, D. R., Francisco, E., \& Laier, R. (2020). Telerehabilitation For Patients With Breast Cancer Through The COVID-19 Pandemic. Breast Cancer Research and Treatment, 0123456789, 35. https://doi.org/10.1007/s10549-02005926-6

Frayon, S., Wattelez, G., Paufique, E., NedjarGuerre, A., Serra-Mallol, C., \& Galy, O. (2020). Overweight in the pluri-ethnic adolescent population of New Caledonia: Dietary patterns, sleep duration and screen time. The Lancet Regional Health Western Pacific, 2, 100025. https://doi.org/10.1016/j.lanwpc.2020.1000 25

Gunawan, G., Fadlyana, E., \& Rusmil, K. (2016). Hubungan status gizi dan perkembangan anak usia 1-2 tahun. Sari Pediatri, 13(2), 142-146.

Haskell, W. L. (2012). Physical activity by selfreport: a brief history and future issues. Journal of Physical Activity \& Health, 9(1), 5-10. 
https://doi.org/10.1123/jpah.9.s1.s5

Hanum, F., Khomsan, A., \& Heryanto, Y. (2014). Hubungan Asupan Gizi dan Tinggi Badan Ibu. Jurnal Gizi Dan Pangan, 9(1), 1-6.

Hidayati. (2010). Obesitas Pada Anak. Jakarta: FK. Unair.

Hillbruner, C., \& Egan, R. (2008). Seasonality, household food security, and nutritional status in Dinajpur, Bangladesh. Food and Nutrition Bulletin, 29(3), 221-231. https://doi.org/10.1177/1564826508029003 08

Kang, S., Sun, Y., Zhang, X., Sun, F., Wang, B., \& Zhu, W. (2020). Is Physical Activity Associated with Mental Health among Chinese Adolescents during Isolation in COVID-19 Pandemic? Journal of Epidemiology and Global Health. https://doi.org/https://doi.org/10.2991/jegh. k.200908.001

Kemenkes. (2020). Pedoman kesiapan menghadapi COVID-19. Pedoman Kesiapan Menghadapi COVID-19, 0-115.

Kosasi, L., Oenzil, F., \& Yanis, A. (2014). Hubungan Aktivitas Fisik terhadap Kadar Hemoglobin pada Mahasiswa Anggota UKM Pandekar Universitas Andalas. Jurnal Kesehatan Andalas, 3(2), 178-181. https://doi.org/10.25077/jka.v3i2.79

Krisnansari, D. (2010). Nutrisi dan gizi buruk. Mandala of Health, 4(1), 60-68.

Mahardika, A, V. (2008). Aktivitas Fisik, Asupan Energi, dan Status Gizi Wanita Pemetik Teh di PTPN VIII Bandung, Jawa Barat.

Nugroho, S. (2015). Peran Nutrisi Bagi

Olahragawan. Medikora, 1, 103-122. https://doi.org/10.21831/medikora.v0i1.470 9

Pahlevi A.E. (2012). Determinan Status Gizi Pada Siswa Sekolah Dasar. Jurnal Kesehatan Masyarakat, $\quad 7(2), \quad$ 122-126. https://doi.org/10.15294/kemas.v7i2.2807
P2PTM Kemenkes RI. (2020). Klasi kasi Obesitas setelah pengukuran IMT. November 2018, 2020.

Riskesdas. (2010). Riset Kesehatan Dasar Tahun2010. Riskesdas 2010, 1-446. https://doi.org/1 Desember 2013

Satrianingrum, A. P., \& Prasetyo, I. (2020). Persepsi Guru Dampak Pandemi Covid-19 Terhadap Pelaksanaan Pembelajaran Daring di PAUD. Jurnal Obsesi: Jurnal Pendidikan Anak Usia Dini, 5(1), 633-640.

Setiati, S. (2008). Vitamin D status among Indonesian elderly women living in institutionalized care units. Acta Medica Indonesiana, 40(2), 78-83.

Sholihin, A. D. (2016). Analisis Aktivitas Fisik Dan Aktivitas Belajar Pada Mahasiswa Fakultas Ilmu Keolahragaan Universitas Negeri Semarang Dalam Memanfaatkan Waktu Luang. JSSF (Journal of Sport Science and Fitness), 4(4), 34-37.

Siregar, N. S. (2014). Karbohidrat. Jurnal Ilmu Keolahragaan, 13(2), 38-44.

Susanto. (2020). Pengaruh Virus Covid 19 Terhadap Bidang Olahraga Di Indonesia. Modos de Ver, 21(1), 1-9. https://doi.org/10.1016/j.solener.2019.02.0 27

Syahruddin, S. (2020). Kebugaran Jasmani Bagi Lansia Saat Pandemi COVID-19. JUARA : Jurnal Olahraga, 5(2), 232-239. https://doi.org/10.33222/juara.v5i2.943

Web Site Resmi Kabupaten Jembrana. Data Kasus COVID-19. Diakses di https://covid19.jembranakab.go.id/\#kejadia $\mathrm{n}$

Web Site Resmi Pemerintah Indonesia. Data Kasus COVID-19. Diakses pada https://covid19.go.id/

WHO. (2010). Global Recomendations on physical activity for health. Global Recomendations on Physical Activity for Health. 
Volume 5, Nomor 2, Tahun 2020: $146-156$

WHO. (2020). Anjuran mengenai penggunaan masker dalam konteks COVID-19. World Health Organization, April, 1-17.

Yuliana. (2020). Olahraga Yang Aman Di Masa Pandemi COVID-19 Untuk Meningkatkan Imunitas Tubuh. Jurnal Bali Membangun Bali, 1(2), 103-110. 